SINAI Journal of Applied Sciences (ISSN: 2314-6079) Vol. (6) Is. (2), Aug. 2017

SINAI Journal of Applied Sciences

\title{
QUALITY EVALUATION OF MULLET FISH TREATED WITH ICE CONTAINING SOME ADDITIVES STORED FOR 15 DAYS
}

\author{
Mosaad M. Ghattas", Amal A. GabAlla ${ }^{1}$, A.A. El-Shibiny ${ }^{2}$ and Seham S. Gad ${ }^{2}$ \\ 1. Dept. Food and Dairy Sci. and Techn., Fac. Agric., Suez Canal Univ., Egypt. \\ 2. Dept. Food and Dairy Sci. and Techn., Fac. Environ. Agric. Sci., Arish Univ., Egypt.
}

\begin{abstract}
The current study was done to evaluate the use of crude isoflavones (CIE), crude rosemary extract (CRE) and CIE plus CRE, as antioxidant and antimicrobial agents in fresh mullet fish during cold storage with ice containing natural extracts for 15 days. The antioxidant and antimicrobial effects of the CIE $0.01 \%$, CRE $0.02 \%$ and CIE $0.01 \%$ plus CRE $0.01 \%$, were evaluated in mullet fish by measuring eye refractive index, moisture content, protein content, fat content, peroxide values (PVs) total volatile basic nitrogen $\mathrm{mg}$ TVB-N/100g content, Free fatty acid (FFA \%, as oleic acid), $\mathrm{pH}$ value, trimethylamine (T.M.A), tiobarbituric acid (TBARS) values, fatty acids (FA), Texture and freshness. Microbiological examinations, total count, coliform count and psychrophilic counts. The data indicated that mullet fish samples containing CIE had retried of lipid oxidation, good freshness scores and better acceptability, even after storage for day 12 at $4^{\circ} \mathrm{C}$.
\end{abstract}

Key words: Mullet fish, soy isoflavone, antioxidant activity, lipid oxidation, peroxide value, tbars, rosemary, antimicrobial.

\section{INTRODUCTION}

Freshness of fish is the most important and fundamental criterion for judging the quality of the final product. Fish is more vulnerable to deterioration than chicken and red meat as it contains relatively larger amounts of free amino acids, a higher water activity and a higher final $\mathrm{pH}$, limiting the shelf life of the product. Spoilage of fish occurs concurrently and independently, their relative importance varying with species of fish (size, lipid content, stage of maturation etc.), environmental conditions (feed availability, temperature, microbial load etc.), method of slaughter and postmortem handling, storage procedures and processing conditions (Lauzon et al., 2010). Biochemical composition of a food (intrinsic factors) and their interrelationship with extrinsic factors during storage, contribute significantly to their freshness and quality partly for the reason that they determine and enhance the initial microbial growth (Huss, 1988).

With regard to fish, the inherent characteristic of the presence of non-protein nitrogen components, such as trimethylamine-oxide (TMAO), creatine, methionine, free amino acids, cystine, histamine, carnosine, volatile nitrogen bases such as urea especially in cartilaginous fishes support microbial growth and the production of their related metabolites; responsible for fish spoilage during storage (Huss, 1988; Huss, 1994). Other parameters affecting freshness and shelf life are related to raw material handling and storage as well as processing and storage conditions of fresh products. Proper utilization of ice both for lowering the temperature of the catch below $0^{\circ} \mathrm{C}$ and maintaining low temperature has proved to be one of the most important factors

\footnotetext{
* Corresponding author: Tel.: +201067997921

E-mail address: mousaadghttas@gmail.com
} 
regarding raw material handling (Lauzon $\boldsymbol{e t}$ al., 2010).

The current study aimed to study the effect of CIE, CRE and CIE + CRE on the quality of mullet fish during stored in crashed ice and its impact on the antioxidant and duration of preservation.

\section{MATERIALS AND METHODS}

\section{Collection of samples}

Soybean (Glycine max) was obtained from the Agriculture Research Centre, Giza, Egypt during season 2014. Rosemary was purchased from a local herb shop (Harraz, Cairo, Egypt). Mullet fish (Mugil cephelus) were collected from Bardewil lagoon.

\section{Preparation of rosemary extract}

Plant materials (rosemary) were used to prepare crude rosemary extract that contain the polar active compounds as following; $10 \mathrm{~g}$ of dry powdered rosemary leaves $(2 \%$ $\mathrm{W} / \mathrm{V})$ were dissolved in distilled water. After maceration for 48 hours, the extract was filtered through filter paper. This filtrate was then frozen and kept at $-18^{\circ} \mathrm{C}$ until used (Georgantelis et al., 2007).

\section{Preparation of crude isoflavones extract from soybean}

Crude isoflavones extract (CIE) from soybean was prepared to be used in a separate experiment with fish preservation to evaluate its antioxidant and antimicrobial effect as follow: soybean seeds were milled for 3 minutes at a medium speed in a coffee bean blender. Then, the particles of the ground whole soy flour were ground to pass through a $1 \mathrm{~mm}$ sieve. The soy flour $(150$ g) was weighed into a thimble to extract the oil by Soxhlet apparatus for 8 hours Fig. 1 . The defatted soy flour $(100 \mathrm{~g})$ was weighed then transferred to round bottom flask, then $400 \mathrm{ml}$ of distilled water was added to it at ratio 1:4 (weight: volume, soy flour: water), then transferred to a flask and incubated at $45^{\circ} \mathrm{C}$ for $5 \mathrm{hrs}$. The mixture was transferred to high speed centrifuge to be clarified for $30 \mathrm{~min}$ at $20^{\circ} \mathrm{C}$ and $5000 \mathrm{rpm}$ speed (RCF g force, 5470). The solid phase was thrown away (discarded).

The clarified solution was transferred to $2 \mathrm{~L}$ round bottom flask to be concentrated under vacuum using rotary evaporator at 35 rpm speed and $55^{\circ} \mathrm{C}$ up till almost reaching the volume of $50 \mathrm{ml}$ of concentrated soybean extract according to Abd Allah (2011).

\section{Preparation of Crashed Ice}

Crashed ice made from clean water mixed with crude isoflavones extract or crude rosemary extracts, was, then, kept at $20^{\circ} \mathrm{C}$ until used.

\section{Preparation of Mullet Fish Samples}

A total number of 50 fresh caught Mulet fish (Mugil cephelus) each fish about $200 \mathrm{~g}$, the fish samples were divided into four groups and treated as follows:

1. First group, control samples (covered with crashed ice).

2. Second group of fish was covered with ice made from water mixed with crude rosemary extract (Rosmarinus officinalis L.), $200 \mathrm{mg} / 1(0.02 \%)$.

3. Third group was covered with ice made from water mixed with crude isoflavones extract (Glycine max), 100mg/1 (0.01\%).

4. Fourth group was covered with ice made from water mixed with $100 \mathrm{mg} / 1(0.01 \%)$ crude rosemary extract (Rosmarinus officinalis L.), w/v. and 100mg/1 (0.01\%) Crude isoflavones extract $\mathrm{W} / \mathrm{V}$.

\section{Analytical Methods}

\section{Chemical Properties}

Water content, $\mathrm{pH}$ values, total protein, peroxide values and fat were determined according to methods described by AOAC (2000). 


\section{Refractive Index of the Eye fluids}

Refractive index of the eye fluids as an index of proteolysis was measured according to the method described by Ghoneim (1974).

\section{Total volatile basic nitrogen (TVBN) and Trimethylamine (TMA)}

The method for determination of TVN and TMA is based on a semi- microdistillation procedure as described by (AMC, 1979).

\section{Thiobarbituric acid reactive substances (TBARS)}

Thiobarbituric acid value was determined as described by Siu and Draper (1978).

\section{Bacteriological examinations}

To determine the microbial counts of total bacterial count, pathogenic bacteria, including psychrophilic count and coliform count were carried out as follow: ten $g$ of fish samples were aseptically transferred to sterile plastic bags containing $90 \mathrm{ml}$ peptone water (Oxoid CM 9, UK). The samples were homogenized for 1-2 $\mathrm{min}$ (Interscience bag mixer 400), then 10-fold serial dilutions were made in sterile peptone salt water up to $10^{-7}$ coliform count were applied using Violet Red Bile (VRB) agar medium. The plates were incubated at $34^{\circ} \mathrm{C}$ for 24 hours coagulase tests were done according to the method described by Siriken et al., (2006). Psychrophiles count was determined in fish samples according to the method mentioned by APHA (1992).

\section{Freshness Evaluation}

Freshness evaluation was determined according to the method mentioned by World Health Organization recommended sheet for fish evaluation according to (Larsen et al., 1992).

\section{Statistical analysis}

All measurements were done in triplicate and data were reported as means \pm standard deviation (SD) using SPSS software (version 16.0 for windows, SPSS Inc., Chicago).

\section{RESULTS AND DISCUSSION}

\section{Physical Indices}

\section{PH Value}

The $\mathrm{pH}$ values increased from 6.60 to 6.97 for control samples (fish stored in crushed ice without any additives), while it increased from 6.56 to 6.68 in samples treated with crude rosemary extract (CRE). It also increased from 6.56 to 6.68 in samples treated with crude isoflavones extract (CIE), and from 6.55 to 6.65 in samples treated both (CIE) and (CRE).

There was a gradual increament in eye refractive index among all treatments as shown in figure 1. Similar results were obtained by Özoğul et al., (2011) and Moustafa (2013).

According to Khouraiba (1981) the increase of $\mathrm{pH}$ value resulted from the proteolysis process which leads to the increase of free basic amino acids as well as the accumulation of ammonia, amines and other basic products of bacterial breakdown.

\section{Eye Refractive Index}

The eye refractive index was increased at all treatments (Fig,2). The eye refractive indices at zero time were $1.3348,1.3347$, 1.3346 and 1.3348 for control, ice with CRE, CIE and their combinations, respectively.

While those values were increased to be $1.3473,1.3423,1.3411$ and 1.3420, respectively at the end of storage period. These results are similar to those reported by El-Naggar (2002) and Moustafa (2013). Such a method may be considered as a simple and routine freshness test, that did not require long time or complicated operations to analyse, like other chemical methods (Ghoneim, 1974). 


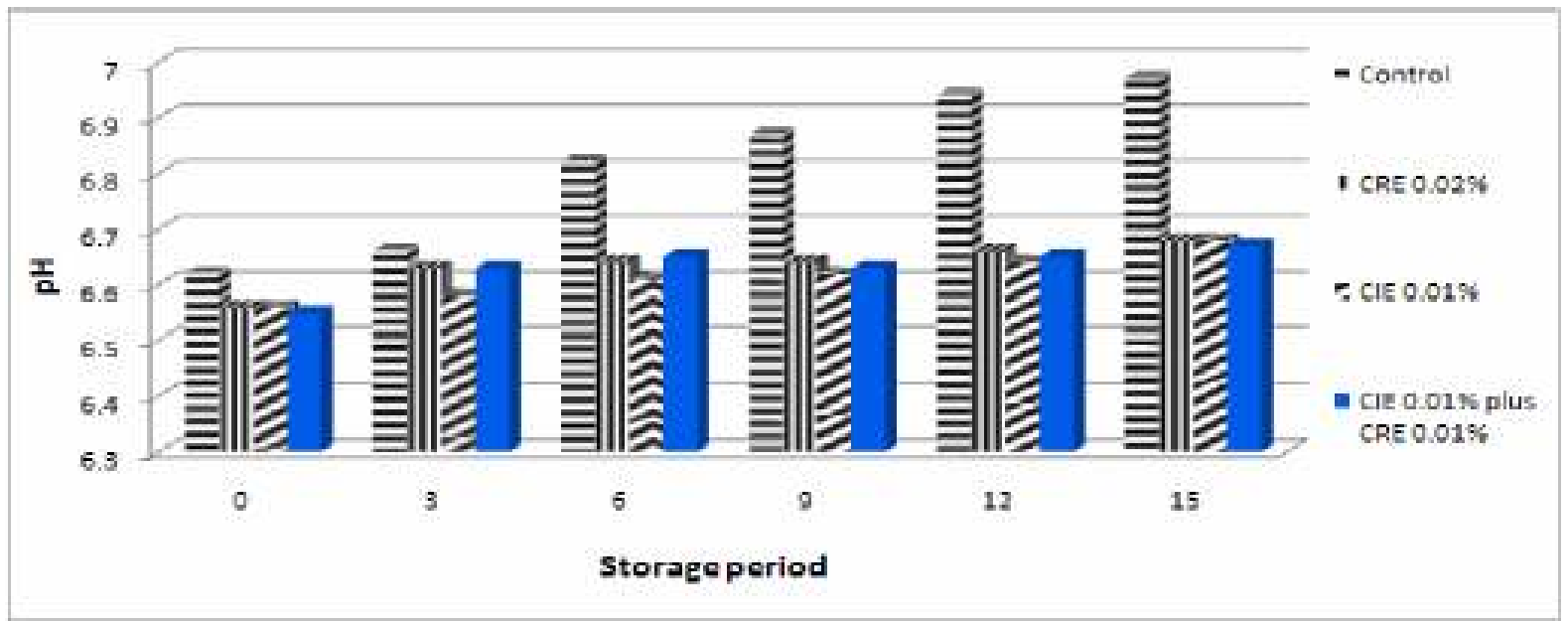

Fig. (1): The changes in pH values in examined mullet fish during storage in ice made from water mixed with CRE, CIE and their combinations.

\section{Chemical Composition}

\section{Protein Content}

The protein contents at zero time were $16.54,16.46,16.52$ and $16.38 \%$ whereas at the day 15 the contnts were decreased to $13.02,14.01,14.27$ and $14.23 \%$ for control, ice with CRE, CIE and their combinations, respectively. Slight decrease in fat content in all treatments of the examined mullet fish during storage in ice made from ice mixed with some plant extracts as shown in Figure 3 . These results were similar to the results obtained by Özoğul et al. (2011) and Mostafa et al. (2015). These decreases in crude protein during storage resulted from the decomposition and degradation of nitrogen substances which may be due to the activity of microorganisms and proteolytic enzymes. These results coincide with those given by Natseba et al. (2005) and Özoğul et al. (2011).

\section{Fat Content}

Results presented in Fig. 4 show slight decrease in fat content in all treatments of the examined mullet fish during storage in ice made from ice mixed with some plant extracts. These results are in agreement with those obtained by Mostafa et al. (2015). The decrease of fat contents may be attributed to the breakdown of fatty acids Babazadeh et al. (2008) and Moustafa (2013).

\section{Total Volatile Based Nitrogen (TVBN)}

The results presented in Fig. 5 show gradual increase in total volatile based nitrogen (mg TVB-N/100g content) in all treatments of the examined mullet fish during storage.

There is a large variation in the development of (TVBN) among all treatments (control, ice made with CRE, ice made with CIE and ice made with CRE plus CIE extracts). As it is shown in Fig. 5 the amounts of (TVBN) at the beginning of the storage period were $9.85,9.67,9.80$ and $9.79 \mathrm{mg}$ TVB- N/100g, while at the fifteenth day of storage period they were $64.60,32.65,30.24$ and $31.59 \mathrm{mg}$ TVB$\mathrm{N} / 100 \mathrm{~g}$ for control, ice with CRE, ice with CIE extract and ice with CRE plus CIE extracts, respectively. These results are similar to the results presented by Köse et al. (2001), Okoro et al. (2010), Özoğul et al. (2011) and Mostafa et al. (2015). 
SINAI Journal of Applied Sciences (ISSN: 2314-6079) Vol. (6) Is. (2), Aug. 2017

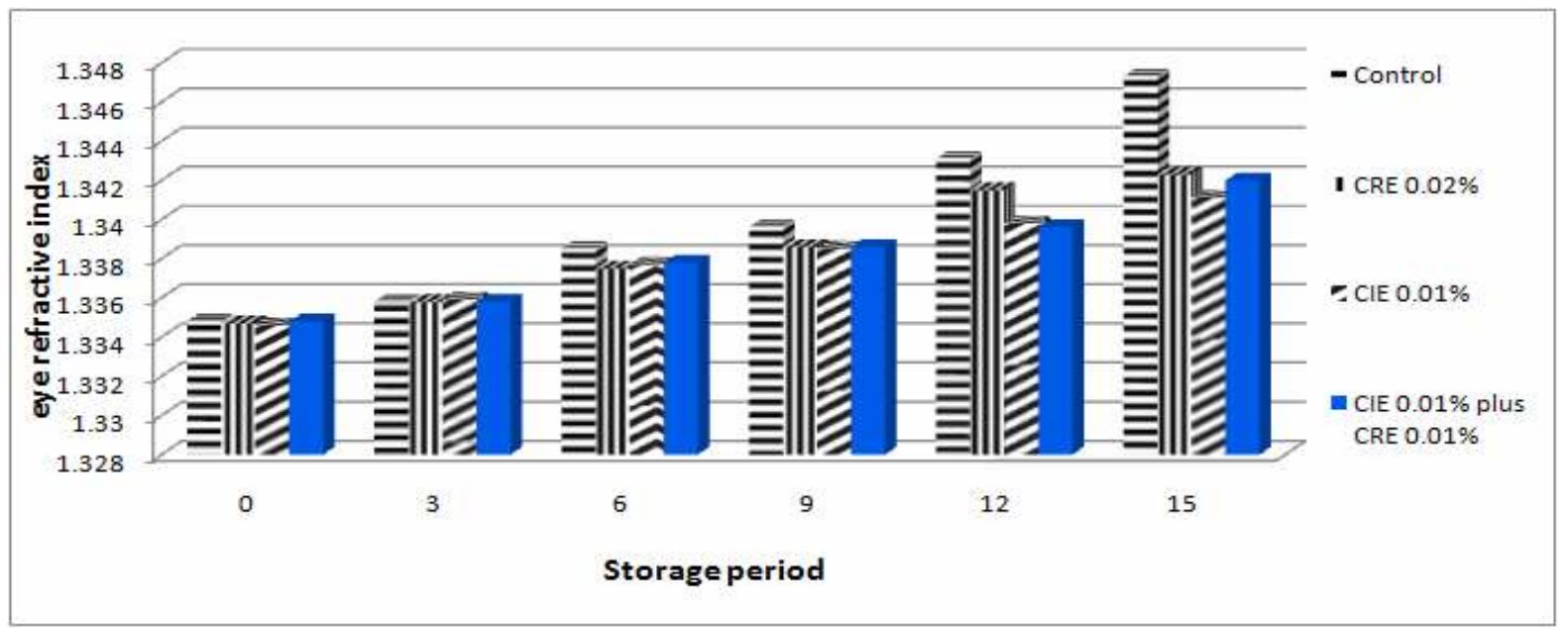

Fig. (2): The changes in eye refractive index in examined mullet fish during storage in ice made from water mixed with CRE, CIE and their combinations.

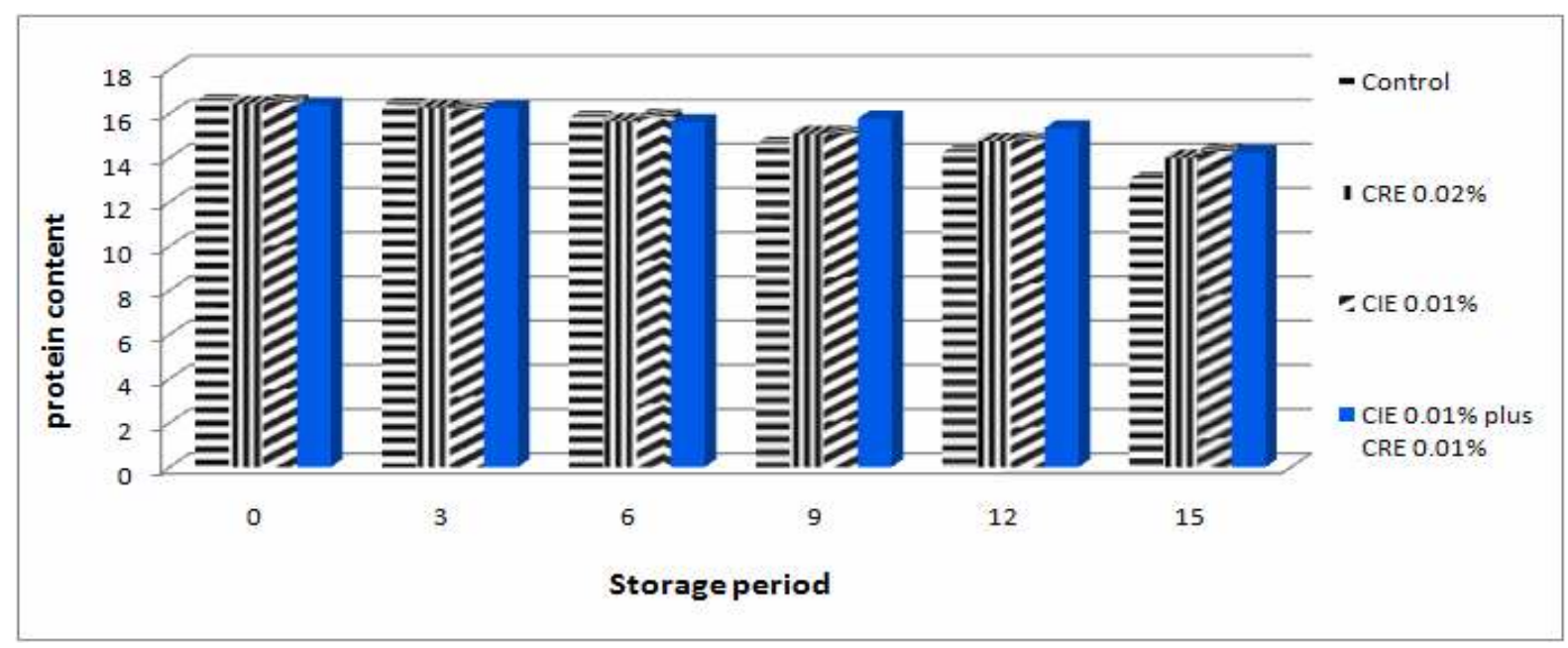

Fig. (3): The changes in protein content of examined mullet fish during storage in ice made from water mixed with CRE, CIE and their combinations.

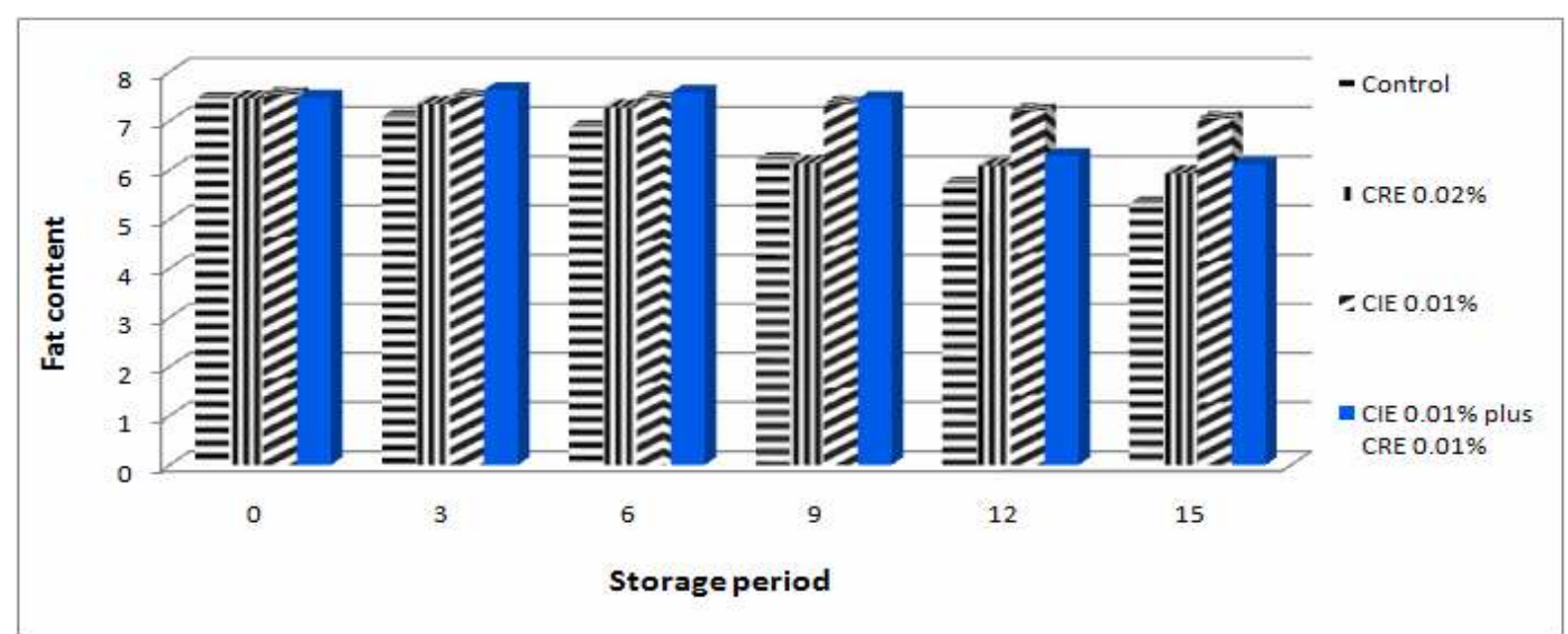

Fig. (4): The changes in fat content of examined mullet fish during storage in ice made from water mixed with CRE, CIE and their combinations. 


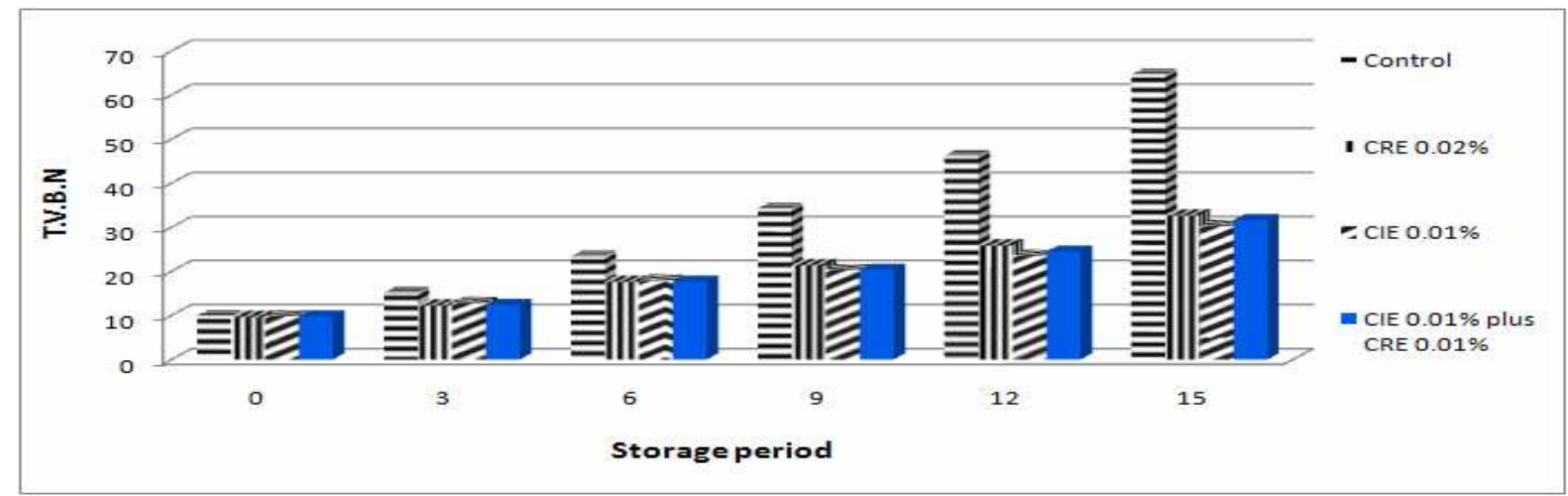

Fig. (5): The changes in total volatile-basic nitrogen (TVBN) of examined mullet fish during storage in ice made from water mixed with CRE, CIE and their combinations.

\section{Trimethylamine (TMA)}

The results presented in Fig. 6 indicate that there was a gradual increase in trimethylamine (TMA) content in all treatments. As it is shown in the figure 6, the highest concentration of TMA valued $23.18 \mathrm{mg}$ TMA/100g, was obtained from mullet fish stored in crashed ice without any additives (control), followed by mullet fish stored in ice mixed with crude rosmary extract, CRE (2.23 mg TMA/100g ), mullet fish stored in ice mixed CIE plus CRE (11.12 mg TMA/100g) and finally mullet fish stored in ice with the CIE $(10.85 \mathrm{mg}$ TMA $/ 100 \mathrm{~g}$ ) at the fifteenth day of storage period. TMA was increased due to bacterial spoilage and enzymatic activity Hebard $\boldsymbol{e t}$ al. (1982) and Moustafa (2013).

\section{Thiobarbituric Acid (TBARS)}

TBA index is a widely used biochemical quality indicator for assessing the level of lipid oxidation in food. TBARS index gives a measure of malonaldehyde formed in the muscle as a result of oxidation of lipid peroxides.

Results presented in Fig. 7 showe a gradual increase in thiobarbituric acid (TBARS) value in all treatments of the examined mullet fish during storage in ice made from water mixed with different additives. The TBARS values of fish covered with crushed ice without any additives (control) increased from 0.56 to $5.33 \mathrm{mg}$ malonaldehyde $/ \mathrm{Kg}$ at the last day of storage, while it increased from 0.53 to 2.42, from 0.54 to 1.75 and from 0.53 to $1.99 \mathrm{mg}$ malonaldehyde/ $\mathrm{Kg}$ in examined mullet fish samples stored in ice with CRE, ice with CIE extract and ice with CRE plus CIE extract, respectively. These results are in agreement with those obtained by Lakshmanan (2000), Moustafa (2013), Viji et al. (2014) and Mostafa et al. (2015). The TBARS values of samples increased gradually during frozen storage, this increase could be attributed to the oxidation of lipids and the formation of some TBA-reactive compounds during the storage period as reported by Stahnke (1995).

TBARS value in the range $1-2 \mathrm{mg}$ malonaldehyde/ $\mathrm{kg}$ of fish sample is usually taken as the limit of acceptability Lakshmanan (2000). In the present study the TBARS values were within the acceptable limit throughout the storage period for all treatments except for control, where considerable fluctuations were shown at figure 7 . It has been stated by Stansby (1963) that lipids in fresh fish tissue held on ice or under refrigeration exhibit a small tendency towards oxidative rancidity. 
SINAI Journal of Applied Sciences (ISSN: 2314-6079) Vol. (6) Is. (2), Aug. 2017

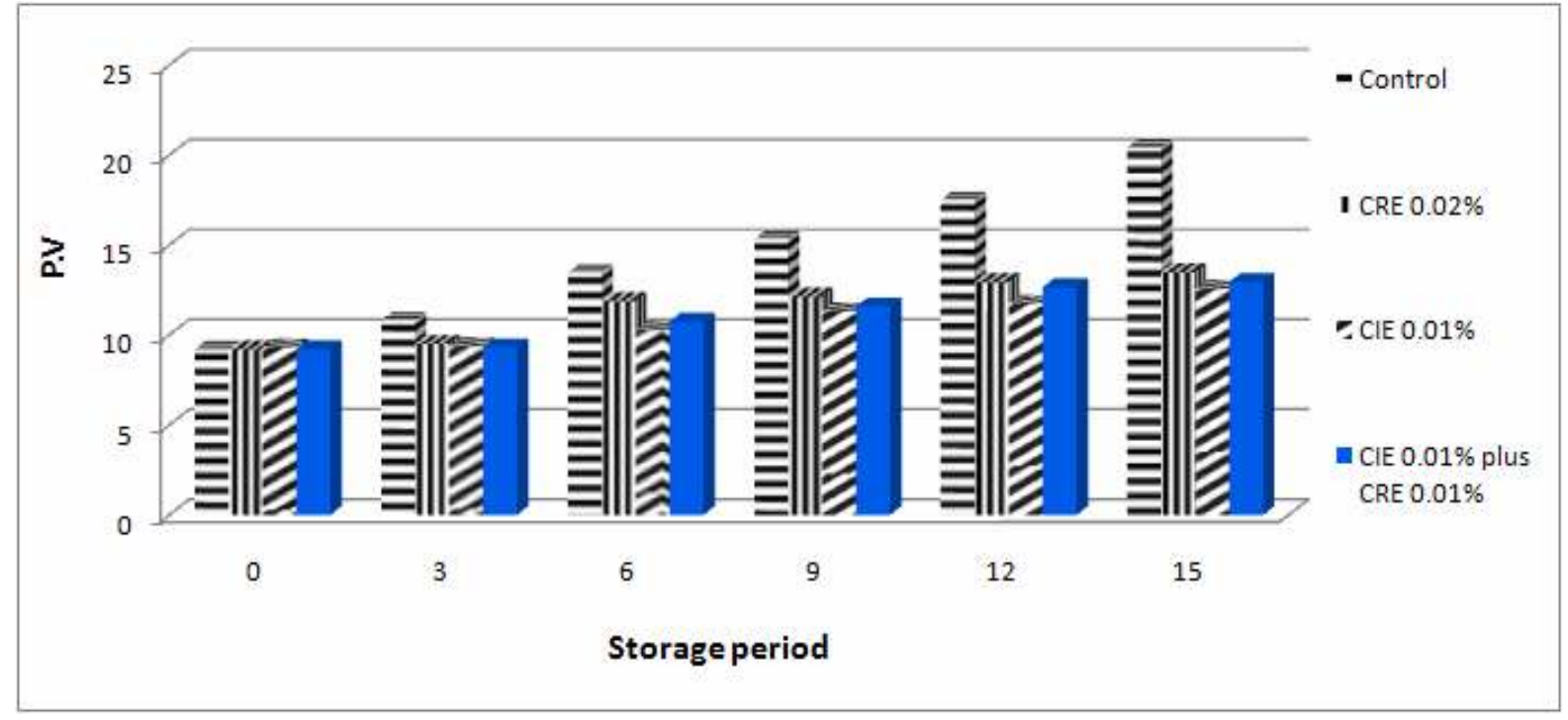

Fig. (6): The changes in trimethylamine (TMA) of examined mullet fish during storage in ice made from water mixed with CRE, CIE and their combinations.

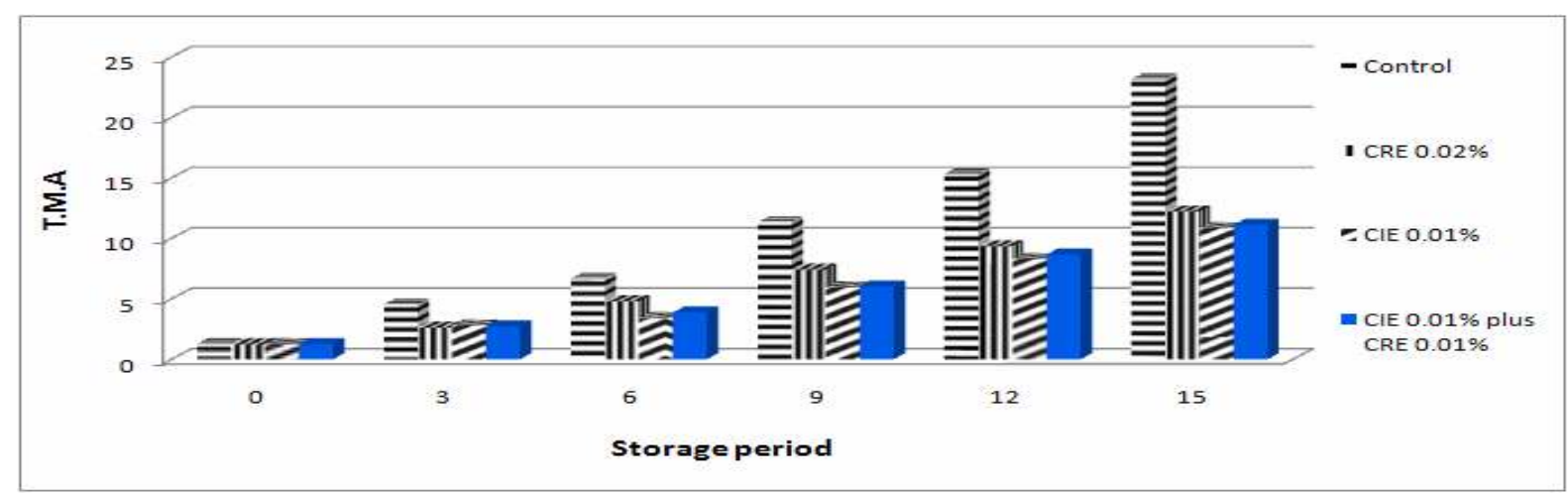

Fig. (7): The changes in thiobarbituric acid (TBARS) of examined mullet fish during storage in ice made from water mixed with CRE, CIE and their combinations.

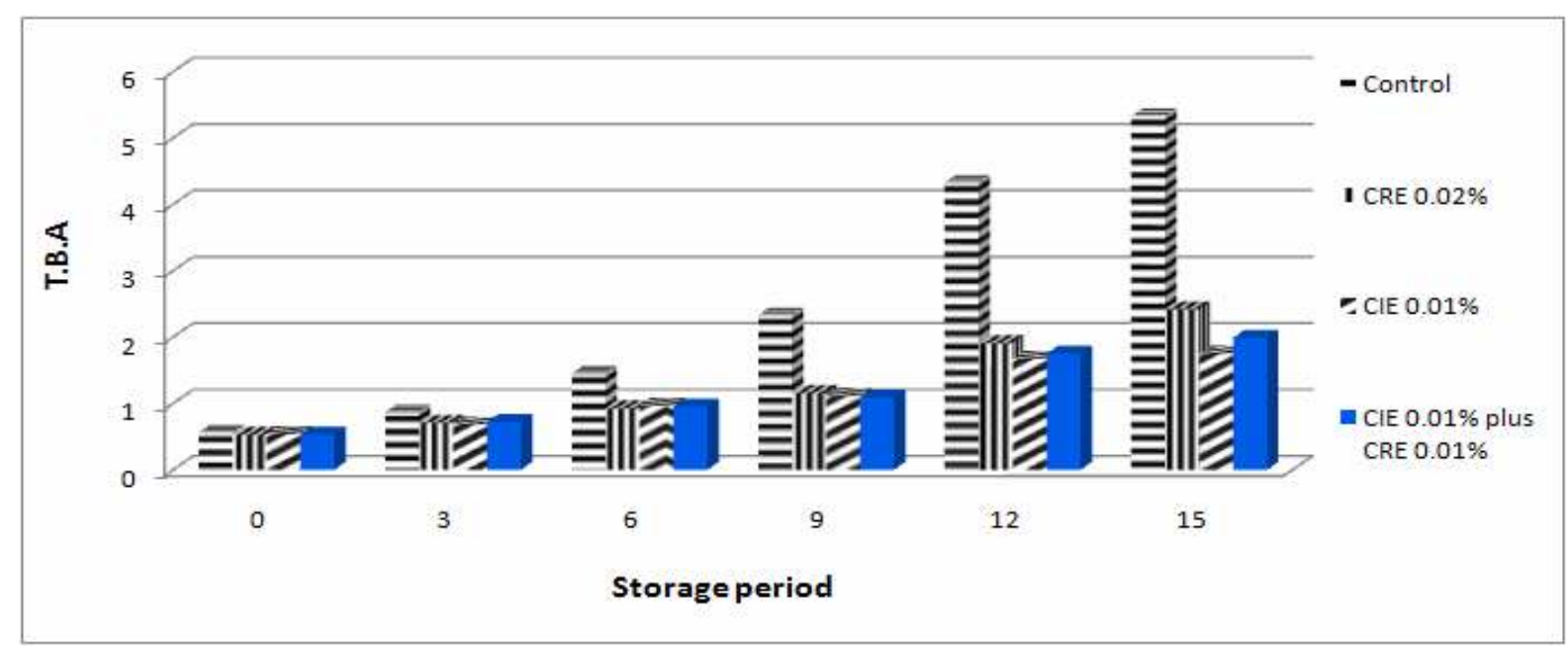

Fig. (8): Changes in peroxide value $P V,(\mathrm{meq} / \mathrm{kg})$ of examined mullet fish during storage in ice made from water mixed with CRE, CIE and their combinations. 


\section{Peroxide Values (PV)}

PV values of fish covered with crushed ice without any additives (control) increased from 9.20 to 20.43 milliequivalent $(\mathrm{mEq})$ peroxide $/ \mathrm{kg}$ fats at the fifteenth day of storage, while it increased from 9.21 to 13.50 (Fig.8), from 9.30 to 12.55 and from 9.20 to 12.95 (mEq) peroxide/ $\mathrm{kg}$ fats in examined mullet fish samples stored in ice with CRE, ice with CIE extract and ice with CRE plus CIE extract individually treated ices, respectively. These results are in agreement with those obtained by Da Silva et al. (2002), Ozyurt et al. (2009) and Vafakhah et al. (2014).

Similar to TBA, the PV of all samples during storage Ozyurt et al. (2009) reported that this characteristic time course of PV was suggested to derive from the preferential oxidation of phospholipids during the early stages of autoxidation. Vafakhah et al. (2014) also reported an increase in TBA and PV with increasing storage time.

\section{Free fatty acid (FFA \%, as oleic acid)}

The FFA of fish covered with crushed ice without any additives (control) increased from 1.95 to 6.65 ( $\%$ as oleic acid) at the fifteenth day of storage, while it increased from 1.95 to 4.55 , from 1.95 to 4.41 and from 1.95 to 4.54 (\% as oleic acid) in examined mullet fish samples stored in ice with CRE, ice with CIE extract and ice with CRE plus CIE extract respectively. These results are in agreement with those obtained by Vafakhah et al. (2014). Moreover, the rate of FFA is changed significantly in all days of storage (Fig. 9).

\section{Microbiological Evaluation}

Total bacterial count continuously increased during cold storage, psychrophilic bacterial counts during cold storage of mullet fish with crushed ice showed increase. Coliform species have not been detected in any of the samples throughout the storage period.

\section{Total bacterial Count (TBC)}

From the results presented in figure 10 indicated that the total bacterial count continuously increased during cold storage of fish under laboratory conditions. Such results agree with those reported by Thanaa (1984).

\section{Total Psychrophilic count (T.P.C)}

Results in Fig. 11 show the psychrophilic bacterial counts during cold storage of mullet fish with crushed ice shwed incresed made with some plant extracts, shows that there was a considerable increase for this kind of bacteria during the cold storage, these results agree with the result reported by Franz (1970) and Frazier (1997). These results are simillar to those reported by Suvanich et al. (2000), Okoro et al. (2010), Winarni et al. (2012) and Mustafa (2013).

\section{Total Coliform Group}

Coliform species have not been detected in any of the samples throughout the storage period, which indicates that there was no contamination with sewage or human feces. These results indicated that Bardawil lagoon is a clean lagoon and produce high quality fish.

Freshness of chilled mullet fish was evaluated by measuring its appearance, eye and gill characteristics, Table 1 shows that chilling of mullet fish in crushed ice mixed with plant aqueous extracts reduced the deteriorations in appearance an index of spoilage. As it is shown in table 1 control samples lost its freshness faster than samples that treated with crushed ice mixed with plant aqueous extracts.

It has been reported by earlier studies that microbial metabolites such as peptides or amino acids, derived from protein hydrolysis, contribute significantly to undesirable freshness changes in seafood products Özogul et al. (2006), Mustafa (2013), Hassanin (2013), Viji et al. (2014) and Moustafa et al. (2015). Fish samples 
SINAI Journal of Applied Sciences (ISSN: 2314-6079) Vol. (6) Is. (2), Aug. 2017

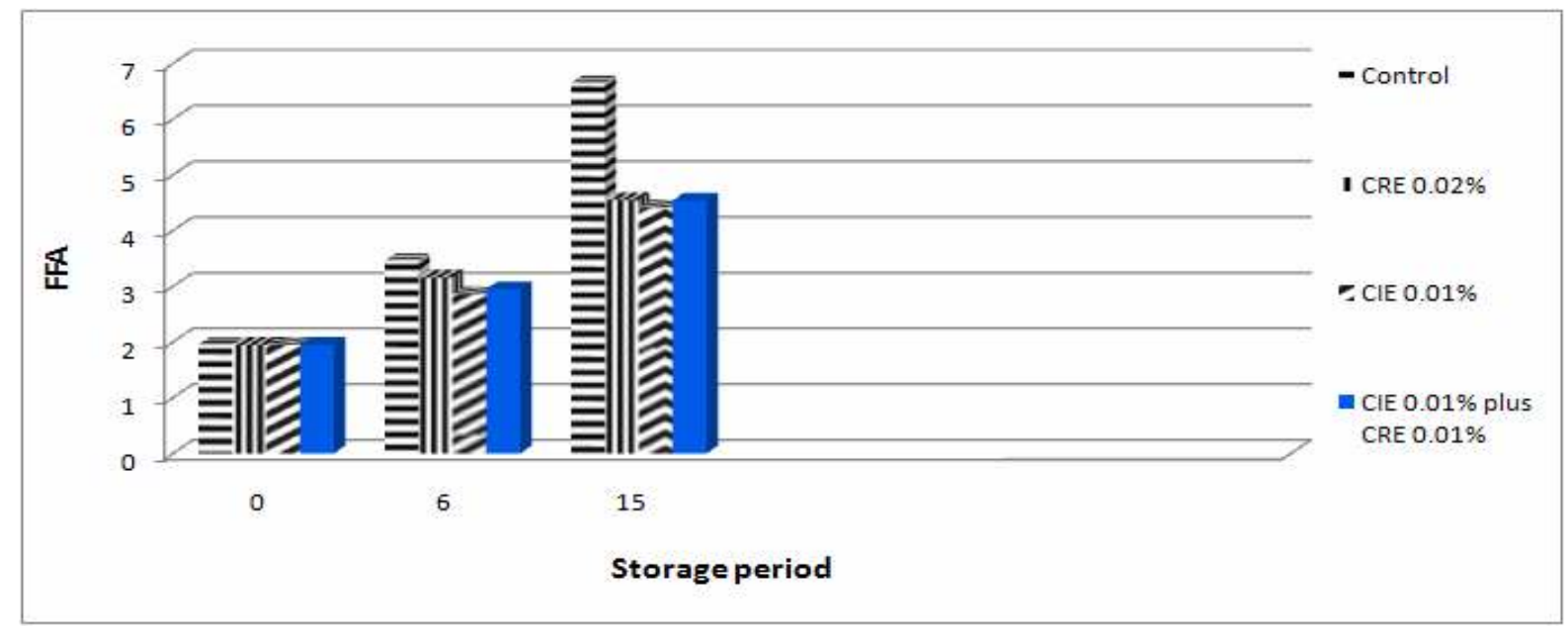

Fig. (9): Changes in Free fatty acid (FFA\%, as oleic acid) of examined mullet fish during storage in ice made from water mixed with CRE, CIE and their combinations.

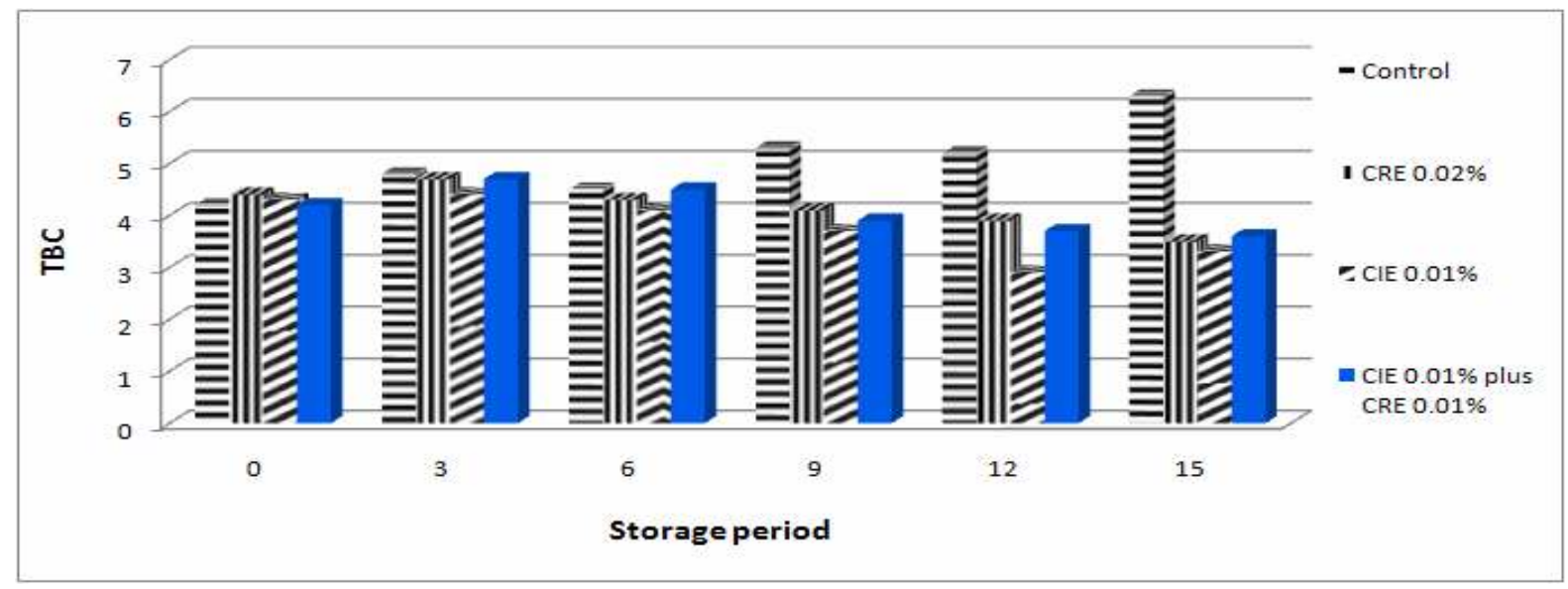

Fig. (10): The changes in total bacterial count (TBC) of examined mullet fish during storage in ice made from water mixed with CRE, CIE and their combinations.

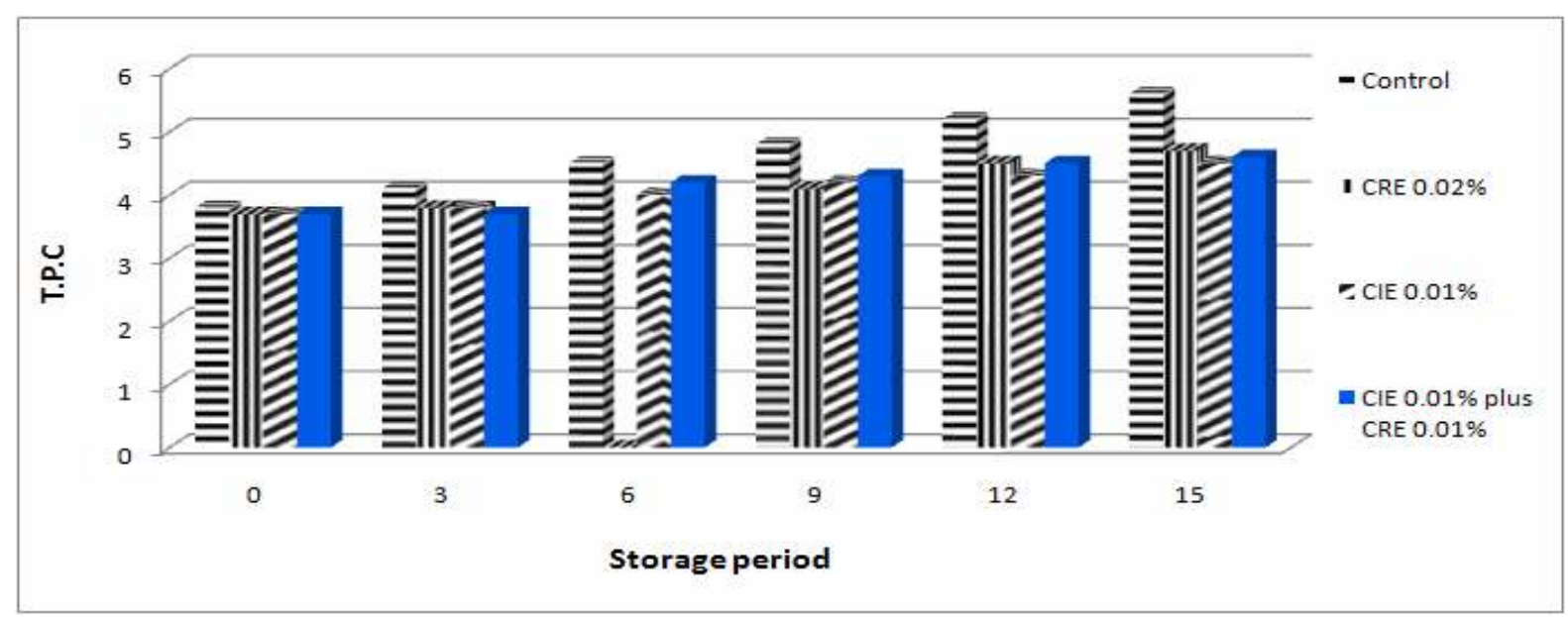

Fig. (11): The changes in total psychrophilic count (TPC) of examined mullet fish during storage in ice made from water mixed with CRE, CIE and their combinations. 
Table (1): Changes in freshness of mullet fish during storage in ice which made from water mixed with CRE, CIE and their combinations.

\begin{tabular}{|c|c|c|c|c|c|c|c|c|c|c|c|c|c|c|c|c|c|c|c|c|c|c|c|c|c|}
\hline \multirow{2}{*}{\multicolumn{2}{|c|}{$\begin{array}{c}\text { Treatment } \\
\text { Storage (Days) }\end{array}$}} & \multicolumn{6}{|c|}{$\begin{array}{c}\text { Control (Crushed ice without } \\
\text { extracts) }\end{array}$} & \multicolumn{6}{|c|}{ Crushed ice with CRE $0.02 \%$} & \multicolumn{6}{|c|}{ Crushed ice with CIE $0.01 \%$} & \multicolumn{6}{|c|}{$\begin{array}{c}\text { Crushed ice with } 0.01 \% \text { CIE plus } 0.01 \% \\
\text { CRE }\end{array}$} \\
\hline & & $\mathbf{0}$ & 3 & 6 & 9 & 12 & 15 & $\mathbf{0}$ & 3 & 6 & 9 & 12 & 15 & $\mathbf{0}$ & 3 & 6 & 9 & 12 & 15 & $\mathbf{0}$ & 3 & 6 & 9 & 12 & 15 \\
\hline \multirow{4}{*}{ 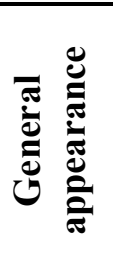 } & skin & 10 & 7 & 4 & 2 & 2 & 2 & 10 & 8 & 5 & 4 & 3 & 2 & 10 & 8 & 7 & 6 & 4 & 2 & 10 & 8 & 7.5 & 6 & 3 & 2 \\
\hline & stiff & 10 & 7 & 3 & 1 & 1 & 1 & 10 & 7 & 5 & 4 & 3 & 2 & 10 & 8 & 7 & 6 & 4 & 2 & 10 & 8 & 7 & 6 & 3 & 1 \\
\hline & Betty & 10 & 7 & 4 & 1 & 1 & 1 & 10 & 7 & 5 & 3 & 2.5 & 1 & 10 & 7 & 7 & 5 & 4 & 1 & 10 & 8 & 7 & 6 & 3 & 1 \\
\hline & odour & 10 & 6 & 3 & 1 & 1 & 1 & 10 & 6 & 5 & 4 & 3 & 1 & 10 & 8 & 7 & 6 & 3 & 2 & 10 & 7 & 7 & 5 & 3 & 2 \\
\hline \multirow{2}{*}{ 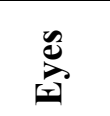 } & clarity & 10 & 7 & 3 & 1 & 1 & 1 & 10 & 8 & 6 & 4 & 3 & 2 & 10 & 8 & 6 & 5 & 3 & 2 & 10 & 8 & 7.5 & 5 & 3 & 2 \\
\hline & shape & 10 & 7 & 3 & 1 & 1 & 1 & 10 & 8 & 5 & 3 & 2.5 & 1 & 10 & 8 & 6 & 5 & 3 & 2 & 10 & 8 & 7.5 & 6 & 3 & 2 \\
\hline \multirow{2}{*}{ 它 } & colour & 10 & 7 & 3 & 1 & 1 & 1 & 10 & 7 & 5 & 4 & 3 & 2 & 10 & 8 & 6 & 6 & 3 & 1 & 10 & 8 & 7 & 5 & 4 & 1.5 \\
\hline & smell & 10 & 6 & 3 & 1 & 1 & 1 & 10 & 7 & 5 & 4 & 2.5 & 1 & 10 & 8 & 7 & 6 & 3 & 2 & 10 & 8 & 7 & 5 & 4 & 1.5 \\
\hline \multicolumn{2}{|c|}{ Iverage } & 10 & .75 & 25 & 1.12 & 1.12 & 1 & 10 & 7.25 & 5.12 & 7 & .81 & 1.5 & 10 & 7.87 & 6.62 & 5.62 & 3.37 & .75 & 10 & 7.87 & 7.18 & 5.5 & 3.25 & 1.62 \\
\hline
\end{tabular}

CIE) Crude Isoflavones Extract and (CRE) Crude Rosemary Extract 
were considered to be acceptable for human consumption until the freshness score reached 4. The results showed that the samples stored in iced mixed with CRE, CIE had a significantly higher freshness score than the control stored throughout the storage period (Viji et al., 2014).

\section{Conclusion}

CIF and CRE are most active as natural antioxidants and antibacterial in fish. These components can delay the chemical changes, retard the microbial growth, maintain the sensory characteristics, and extend the shelf-life of fish during storage. CIF, CRE and plant extracts can be utilized as safe methods for the preservation of fish during storage.

\section{REFERENCES}

Abd Allah, A.M. (2011). Effect of using some plant extracts on some food products, Fac. Environ. Agric. Sci., Suez Canal Univ., Egypt.

AMC. (1979). Recommended methods for the examination of fish and fish products. Analyst, 104-433.

AOAC (2000). Official Methods of Analysis of the Association of Analytical Chemists (18 ${ }^{\text {th }}$ Ed.). Washington, DC, USA.

APHA (1992). American Public Health Association. In C. Vanderzant and D.F. Splittsloesser (Eds.), Compendium of methods for the microbiological examination of foods $\left(3^{\text {rd }}\right.$ Ed.) Washington, DC. APHA.

Babazadeh, M.; Kousha, A. and Safari, R. (2008). Changes in Nutritional Factors of Freezed Kutum (Rutilus frisii kutum). World J. Zool., 3: 51-53.

Da Silva, Ligia Virginia Antonia da. (2002). Hazard Analysis Critical Control Point (HACCP), Microbial Safety, and Shelf Life of Smoked Blue Catfish.
El-Naggar, A.H. (2002). Effect of some medical plants on fish freshness during handling and transportation after fishing, M.Sc. Thesis, Fac. Environ. Agric. Sci., Suez Canal Univ., Egypt.

Franz, E. (1970). Plant hygienic aspects of the fish processing industry, Allemande fish Wirtschaftszeilung, 22 (1): 123-126.

Frazier, W.S. (1997). Food Microbiology. Mc Graw Hill Publ. Comp. $4^{\text {th }}$ Ed., Bombay, New Delhi.

Ghoneim, S.I.M. (1974). Comparative studies on the freshness indices of fish. M.Sc. Thesis, Fac. Agric, Ain Shams Univ., Egypt.

Georgantelis, D.; Ambrosiadis, I.; Katikou, P.; Blekas, G. and Georgakis, S.A. (2007). Effect of rosemary extract, chitosan and $\alpha$-tocopherol on microbiological parameters and lipid oxidation of fresh pork sausages stored at $4^{\circ} \mathrm{C}$. Meat Sci., 76 (1): 172-181.

Hassanin, S.I.A. and El-Daly, E.A. (2013). Effect of Propolis and Garlic on Nile Tilapia Oreochromis niloticus fillets during frozen storage. Proc. and Quality Control Dept., Cent. Lab. Aquac. Res., Agric. Res. Cent., Dept. Meat Hygiene, Fac. Vet. Med., Zagazig Univ. Egypt, 8 (1): $237-248$.

Hebard, C.E.; Flick, G.J. and Martin, R.E. (1982). Occurrence and significance of trimethylamine oxide and its derivatives in fish and shellfish. In Chem. and Biochem. Marine Food Prod., 149-304.

Huss, H.H. (1988). Fresh fish: Quality and quality changes. FAO Fisheries Series, 29-132.

Huss, H.H. (1994). Assurance of Seafood Quality. FAO Fishery Technol. Pap. No. 334.

Khouraiba, H.M.A. (1981). Extension of storage ability of certain Nile Fish Using Gamma Irradiation, M.Sc. Thesis, Fac. Agric, Zagazig Univ., Egypt. 
Köse, S. and Mehmet, E.E. (2001). Quality changes of whiting (Merlangius merlangus euxinus, N. 1840) stored at ambient and refrigerated temperatures, Turkish J. Fisheries and Aquatic Sci., 1: 59-65.

Lakshmanan, P.T. (2000). Fish spoilage and quality assessment. In T.S.G. Iyer, M. K. Kandoran, Mary Thomas, and P. T. Mathew (Eds.), Quality Assurance in Seafood Proc. (26-40). Cochin: Soc. Fisheries Technol. (India).

Lauzon, H.L.; Margeirsson, B.; Sveinsdóttir, K.; Guðjónsdóttir, M.; Karlsdóttir, M.G. and Martinsdóttir, E. (2010). Overview on fish quality research. Impact of fish handling, processing, storage and logistics on fish quality deterioration. Nýsköpun og neytendur, Skýrsla Matís 39-10, Nóvember, ISSN: 1670-7192.

Mostafa, A.A. and Salem, R.H. (2015). Characterization of Microbiological and Nutritional Variations in Processed Mullet (Mugil cephalus) Fish, Int. J. Microbiol. Res., 6 (2): 108-122.

Moustafa, M. (2013). Use of Some Non Traditional Materials in Fish Preservation. MSc. Thesis. Fac. Environ. Agric. Sci. Suez Canal Univ., Egypt.

Natseba, A.; Lwalinda, I.; Kakura, E.; Muyanja, C.K. and Muyonga, J.H. (2005). Effect of pre- freezing icing duration on quality changes in frozen Nile perch (Lates niloticus). Food Res. Int., 38: 469-474.

Okoro, C.C.; Olusimbo, O.A. and Babajide, O.J. (2010). Quality assessment of a nigerian marine fish, mullet (Liza falcipinnis) under different storage sonditions. New York Sci. J., 3 (8): 1554- 0200.

Özogul, Y.; Özogul, F.; Kuley, E.; Özkutuk, A.S.; Gökbulut, C. and Köse, S. (2006). Biochemical, sensory and microbiological attributes of wild turbot (Scophthalmus maximus), from the Black Sea, during chilled storage. Food Chem., 99 (4): 752 - 215.

Özoğul, Y.; Esmeray, K.B.; Bahar, T. and Fatih, Ö. (2011). Changes in biochemical, sensory and microbiological quality indices of common sole (Solea solea) from the Mediterranean Sea, During Ice Storage, Turkish J. Fisheries and Aquatic Sci., 11: 243-251.

Ozyurt, G.; Esmeray, K.; Serhat, O. and Fatih, O. (2009). Sensory, microbiological and chemical assessment of the freshness of red mullet (Mullus barbatus) and goldband goatfish (Upeneus moluccensis) during storage in ice, Food Chem., 114: 505-510

Siu, G.M. and Draper, H.H. (1978). A survey of the malonaldehyde content of retail meats and fish. J. Food Sci., 43 : 1147-1149.

Stahnke, L.H. (1995). Dried sausage fermented with Staphylococcus xylosus at different ingredient levels Part I. Chem. and bacterial. data. Meat Sci., 41: 179-191.

Stansby, M.B. (1963). Composition of fish. In: Industrial Fishery Technology. Bobert E. Krieger Publishing Co., Huntington, Network, 370.

Suvanich, V.; Marshall, D.L. and Jahncke, M.L. (2000). Microbiological and color quality changes of channel catfish frame mince during chilled and frozen storage. J. Food Sci., 65 (1): 151-154.

Thanaa, M.H.E. (1984). Chemical, Physical and Histology Studies on Super Chilled Fish, Ph.D. Thesis, Fac. Agric., Zagazig Univ., Egypt.

Vafakhah, F.; Oraji, H. and Javaheri, B.M. (2014). Lipid quality in benni (Barbus sharpeyi) fillets during ice storage Int. J. Biosci. IJB., 4 (6): 109116. 
Viji, P.; Tanuja S.; George, N.; Zynudheen, A.A. and Lalitha, K.V. (2014). Quality characteristics and shelf life of sutchi cat fish (pangasianodon hypophthalmus) steaks during refrigerated storage, fish processing division, central institute of fisheries technology, Matsyapuri P.O, Willington Island, Cochin, India, Int. J. Agric. and Food Sci. Technol., 105-116.
Winarni, A.; Eko, S.; Ismail M.A. and Mohammad, S.R. (2012). Effect of alloe vera (Alloe vera) and crown of god fruit (Phaleria macrocarpa) on sensory, chemical, and microbiological attributes of Indian mackerel (Restrelliger neglectus) during ice storage, Int. Food Res. J., 19 (1): 119-1. 


\section{الملخص العربي}

تقييم جودة الأسماك المعاملة بالثتج المحتوى على بعض الإضافات المخزن لمدة ه 1 يوم

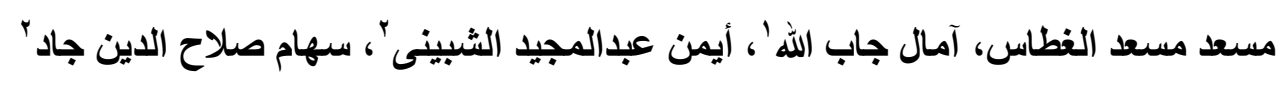

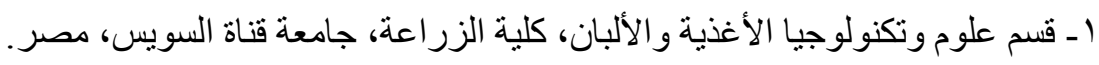

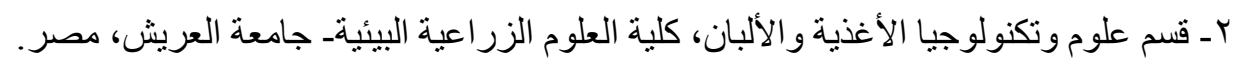

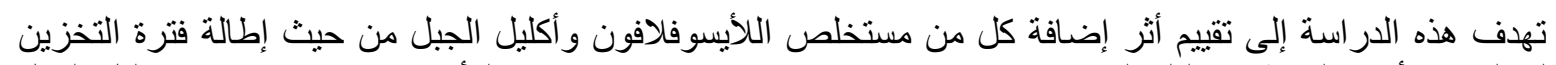

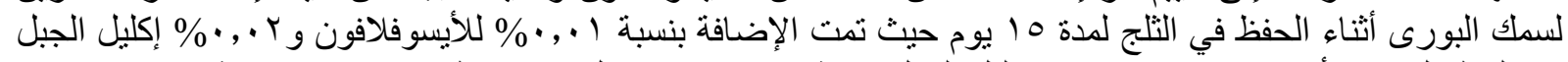

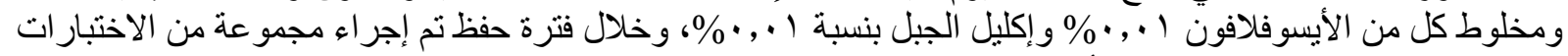

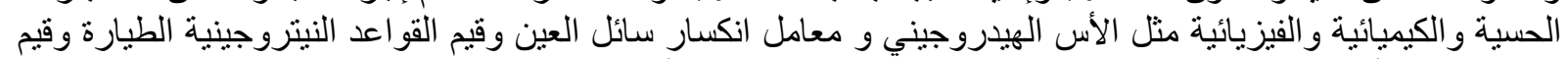

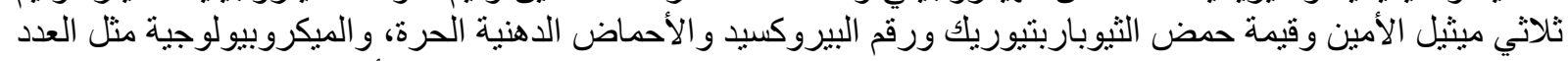

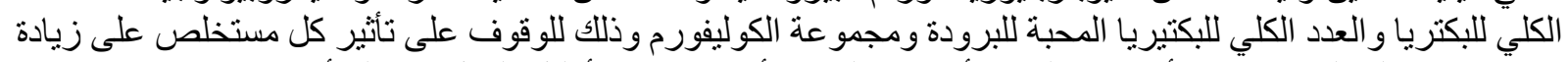

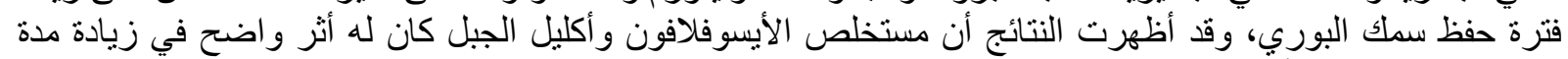

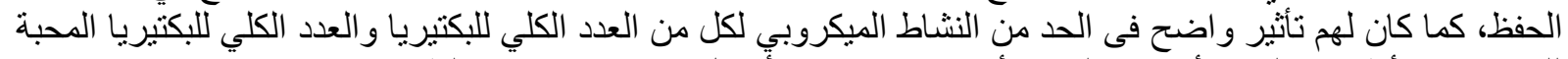

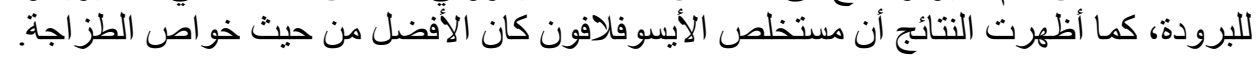

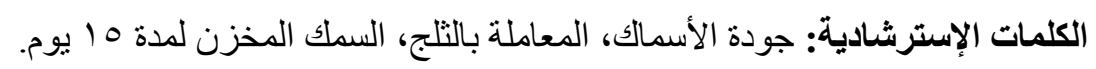

